\title{
Technology Acceptance of E-Banking Services in an Unnatural Environment
}

\author{
Adeyemi Adepoju ${ }^{(1 *}$, Adebola Adeniji ${ }^{2}$ \\ 1,2 Federal University of Technology Akure, Department of Project Management \\ Technology, Akure, Nigeria \\ * Corresponding author: aoadepoju@futa.edu.ng
}

Article History
Received 2020-03-15
Revised 2020-04-21
Accepted 2020-04-22
Published 2020-05-06

Keywords

E-banking

Technology Acceptance Model

E-banking

Unnatural Environment

Nigeria

\section{How to cite?}

Adepoju, A., \& Adeniji, A. (2020).

Technology Acceptance of E-Banking

Services in an Unnatural Environment SEISENSE Journal of Management, 3(3), 34-50.

doi:10.33215/sjom.v3i3.336

\begin{abstract}
Purpose- The effect of technology acceptance of e-banking services on satisfaction has been well studied in a system. It is characterized as being in a state of orderliness; however, there is the dearth of study in an unnatural environment, among others.

Design/Methodology- Data were collected through a structured questionnaire from 304 staff of Federal Medical Centre, Owo, Nigeria, that were selected using a random sampling technique. The study hypotheses were assessed with PLS-SEM methodology.

Findings- Findings from the study suggest that the customers' level of perceived usefulness of e-banking pays more considerable attention to the e-banking channels, implying that the usefulness of the technology is considered crucial among the respondents. The SEM results showed that the relationship was positive and significant with small effects.

Practical Implications- Customers of e-banking placed emphasis on perceived usefulness in an environment characterized as unnatural.
\end{abstract}




\section{Introduction}

Electronic banking is a necessity in the transformation and competitiveness of banks in this present day. Although, apart from enhancing the improvement in efficiency and service quality, it also attracts the retention of customers (Kannabiran \& Narayan, 2005). According to (Amin, 2016), e-banking contributes significantly to the distribution systems of banks, including automated teller machines (ATM), phone banking, telebanking, personal computer banking, and now internet banking. Furthermore, Sedgwick (2017) posited that e-banking offers other avenues for the products and services of banks to be sold to their customers. In the time past, acceptance of electronic technology has been widely researched upon when the environment was conducive for decision making, but a dearth of study exists for a situation that was unnatural. An unnatural environment is characterized by constraints, which could also be likened to a decision making under the condition of risk where more than a state of nature exists, but there is information to support the eventual decision. Technology Acceptance Model (TAM) is a theory that simulates the acceptance of technology by its users. It suggests two theoretical constructs, which are fundamental determinants of user acceptance that is perceived usefulness (PU) and perceived ease of use (PEOU). The present study investigated the acceptance of the electronic banking system and the satisfaction of the staff of the Federal Medical Centre, Owo, Ondo State. This became necessary due to the recent happening in the town and the aftermath behavior of the people living in the area. There was an armed robbery attack on four deposit money banks in Owo, Ondo State Nigeria, on 26th March 2015, which left the community in a deplorable situation. Six weeks after the robbery attack, the banks could not open for businesses in spite of security guarantees from the Nigerian police. However, customers of the affected banks in the town have had to seek services in other branches of the banks outside the town or use electronic banking channels (Premium Times, 2015). The situation is aggravated due to shortage of daily hours of operations by the banks in the town in order to forestall further occurrence. The resultant effects has been customers' frustration with long queues and the manual operations over stressed. Invariably, it believed that this should encourage customers to embrace e-banking services, although some customers seems not to be satisfied with electronic banking due to issues such as security, connectivity, and accessibility. Thus, in a chaotic or unnatural environment the study investigated the acceptance of electronic banking system and satisfaction of the staff of Federal Medical Centre, Owo, Ondo State, Nigeria. The derivative study specific objectives are to:

i. $\quad$ assess the level of perceived usefulness and perceived ease of use of electronic banking system in Federal Medical Centre, Owo;

ii. examine the extent of satisfaction of the staff of the Federal Medical Centre, Owo in the electronic banking system; and

iii. evaluate the effects of perceived usefulness, perceived ease of use, and actual system use of electronic banking system on the extent of satisfaction of the staff of Federal Medical Centre, Owo.

\section{Literature Review}

In 1986 technology acceptance model (TAM) was developed by Davis as reported by Akinwale \& Adepoju (2019). It opined that the model contains some vital ingredients on acquisition, learning, acceptance, and usage of technology. It is a model that explains how external variables influence belief, attitude, and intention to use a particular technology. The literature review has been executed to reflect the positions of authors on the relationship among the variable constructs of interest.

The research conducted by Karjaluoto et al. (2009) was on the antecedents of online banking satisfaction and loyalty in Finland. The study provided a mixed relationship between perceived usefulness (PU) and perceived ease of use (PEOU) on satisfaction. It was posited that the path of PEOU to satisfaction was positive and 
significant, whereas PU was positive and insignificantly related to satisfaction. The study concluded that PEOU is a more reliable determinant of satisfaction than PU in the study area. Also, among the self-service technologies such as the online banking Chen et al. (2009) examined the concepts of technology readiness, TAM, and theory of planned behavior. The study found among other results that PU and PEOU were important significant motivators of satisfaction. George \& Kumar (2013) conducted a study on the antecedents of customer satisfaction in internet banking using the constructs of TAM. They reported that young males, well-educated employees with a moderately high income, are the significant users of internet banking in the environment. The study further reported a positive and significant relationship between constructs of PU and PEOU on customer satisfaction. In the same vein, the study conducted by Akinyemi et al. (2013) was on the acceptance and satisfaction of the e-banking system as s panacea for the cashless economy in Nigeria. Based on the two constructs of TAM; PU and PEOU as the fundamental determinants of acceptance, the study assessed the e-banking system attitude of users. It was revealed that PU and PEOU have a positive and significant relationship with the user attitude to the technology. Amin et al. (2014) were on the studies that examined PU, PEOU, and trust in mobile user satisfaction. Employing SEM (covariance-based), the study found PU and PEOU having a positive relationship with the mobile user satisfaction. The study further opined that PU was the main predictor factor for trust, which invariably strengthens its position for customer satisfaction and loyalty.

Likewise, Tang \& Huang (2015) showed the impact of PU and PEOU on the electronic satisfaction of customers using an online platform for purchases. The study employed a covariance-based structural equation modeling (SEM) and found contradicting results to that presented by Karjaluoto et al. (2009). Tang and Huang found that PU showed a positive and significant relationship with e-satisfaction, but the relationship between PEOU and e-satisfaction was weak and insignificant. Agrebi and Jallais (2015) also found a positive and significant effect of PU and PEOU on customer satisfaction on their intention to use smartphones for purchases. A study also examined the key predictors influencing customer satisfaction towards online retailing in the context of an emerging economy (Tandon et al., 2016). The findings revealed the PU, PEOU, and website design have positive impacts on satisfaction. However, the PU indicator emerged as the strongest predictor of customer satisfaction. Based on TAM, Ghani et al. (2017) investigated customer service and customer satisfaction to provide information on internet banking adoption issues in Pakistan. While the study employed the variance-based SEM, they found a positive and significant relationship between PU and PEOU on customer satisfaction. The results also disclosed that the effect of PU was almost four times the path coefficient of PEOU on customer satisfaction.

Recently, Vuković et al. (2019) employed the logistic regression models to find the relationship between the two main elements of TAM (PU and PEOU) and the acceptance of internet banking. Their study found a positive and significant relationship between variables of TAM and internet banking acceptance in the city of Split in Croatia. The logistic results also disclosed PU is having an odder ratio than the PEOU. In Indonesia, Ding et al. (2019) focused on single university-based research and examined the role played by PU and PEOU on the acceptance of IT. The study based on stratified random sampling to select 98 students and multiple linear regression as a statistical technique. The results were consistent with the earlier researchers' positive and significant PU and PEOU on the acceptance of IT. However, the study found PEOU as the dominant variable having more influence on the acceptance of a multipurpose system than PU. Another study adopted extended TAM by integrating other variables such as technology anxiety and personal innovativeness (Gbongli et al., 2019). They made use of VB-SEM and artificial neural network and concluded that PEOU was the most significant factor affecting consumer attitude to mobile-based money compare to the PU. The explanation given was that PEOU, mobile money services remain a relatively new phenomenon in the field of e-business and that most mobile financial companies are still in an early stage of diffusion. This made users delay their adoption by waiting patiently to know the intrigues and may not want to be a sacrificial lamb until the technology matures. 
In contrast, the impact of PU on attitude suggested being a circumstance of a perceived relative advantage as users would desire to know whether the new technology process surpassed the previous in terms of its benefit. Similarly, Islam (2011) also validated the extended TAM by incorporating computer self-efficacy and satisfaction into the original TAM. The study employed the CB-SEM, and with five significant faculties, the results established that PEOU had a statistical influence on technology satisfaction among the students.

Also, Isaac et al. (2017) researched the internal usage of government institutions in Yemen. The study examined the effect of extended TAM on the performance impact, which they modeled as a reflective-reflective secondorder construct. The outcome showed that PU PEOU has a positive relationship with the actual usage, which in turn has a significant effect on the performance impact. The result further disclosed a higher impact on PU than PEOU. Subsequently, in the following year, Isaac et al. (2018) again surveyed 508 internet users among government employees. This was intending to explain and predict actual usage, among other things. They adopted the procedure of CB-SEM with AMOS. Their results revealed a positive and significant relationship between PU and PEOU on user satisfaction.

Nevertheless, a positive and insignificant relationship exists between actual usage and user satisfaction. However, it was evident from their structural paths that actual usage had been expressed as a mediator for both PU and PEOU constructs in the same model. This could have significantly influenced the obtained results. It is an indication that actual usage may not be a mediator for the PU and PEOU relationship with user satisfaction in the study. The results of the study also favor PU as having more impacts on actual usage and user satisfaction than PEOU had on both constructs. Recall, it is evident from past literature that many studies have included PU and PEOU more than the actual system use (ASU) in their studies. The work of Ayo et al. (2016) also followed the same outcome as that of Isaac et al. (2018), but this study path direction was from satisfaction to actual use of the system. It was also evident from the study that customer satisfaction had been used as a mediator between e-service quality and actual use, hence a similar trend in the obtained results.

It is also noted that much of the studies were not conducted under an environment characterized by a strange situation. This study has been conducted to fill this gap in the literature as well as correct the anomaly in the path to actual use. Therefore, based on the reviewed literature, the study proposes the following hypotheses following the third objective of the study.

$\mathrm{H}_{1}: \mathrm{PU}$ is positive and significantly related to customer satisfaction.

$\mathrm{H}_{2}$ : PEOU is positive and significantly related to customer satisfaction.

$\mathrm{H}_{3:}:$ ASU has a positive and significant relationship with customer satisfaction.

\section{Conceptual Framework}

The conceptual framework is adapted from the study of Davis (1989) on Perceived Usefulness, Perceived Ease of Use, and User Acceptance of Information Technology (Figure 1). This study used perceived usefulness (PU), perceived ease of use (PEOU), and actual system use (ASU) as variables measuring the technology acceptance of electronic banking system (independent variable). 


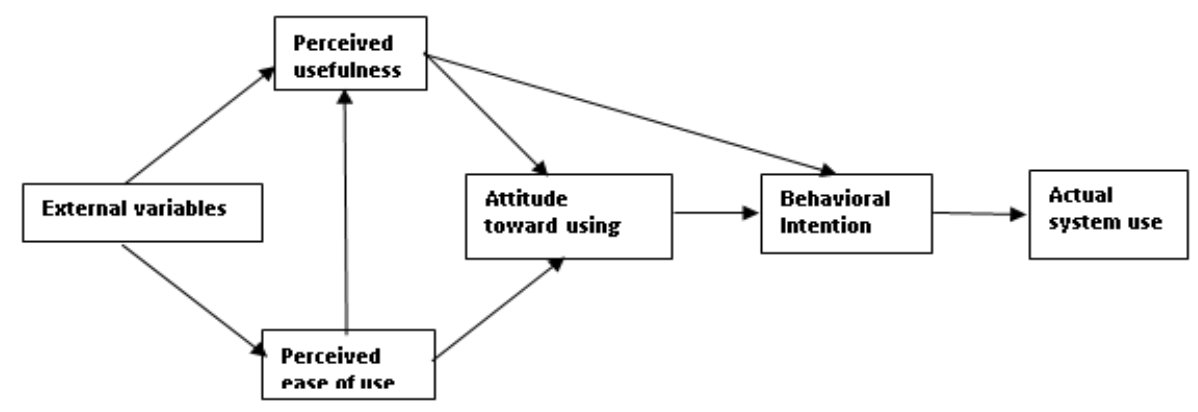

Figure 1 - Technology Acceptance Model (TAM) (Davis, 1989)

While time-saving, electricity availability, speed of transaction, easy banking operations accessibility, limited unnecessary costs, adaptability, affordability, access transaction records, acceptable levied fees, security, the proximity of electronic banking channels and network service were used as variables measuring the level of staffs e-banking satisfaction (dependent variables) (as shown in Figure 2).

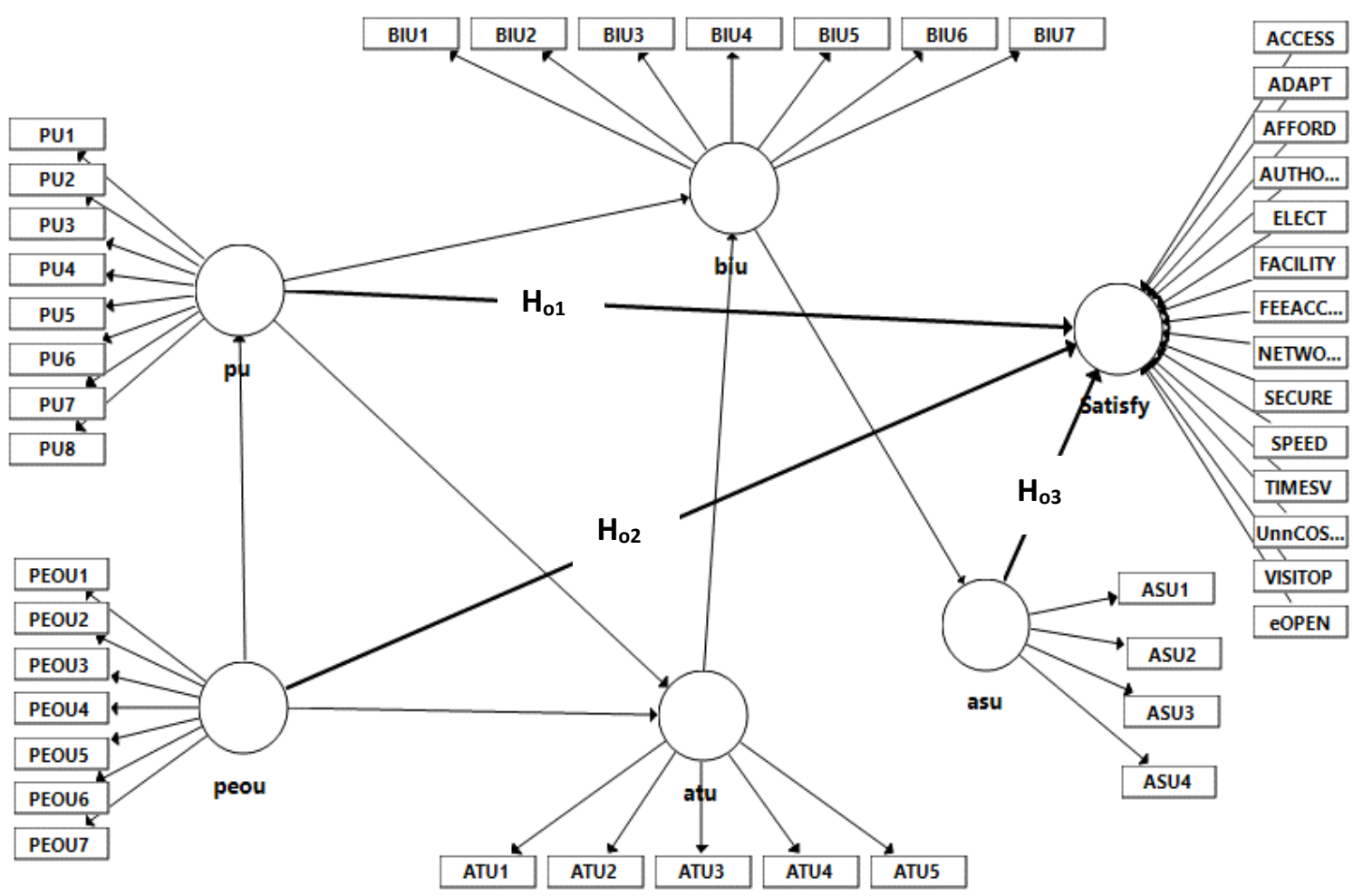

Figure 2 - Conceptual Framework

Key: TIME - Time-Saving; ELEC - Electricity Availability; SPEED - Speed of transactions; EASY - Easy banking operations; ACCESS - Accessibility; UnnCOST- Limited unnecessary costs; ADAP - Adaptability; AFFORD - Affordability; AUTHORIZE - Access transaction records; FEEACC - Acceptable levied fees; SECURE - Security; FACILITY - Proximity of electronic banking channels; NETWORK - Network Service; PU - Perceived Usefulness; PEOU - Perceived Ease of Use; ATU- Attitude toward use; BIU- Behavioral intention to use; ASU- Actual system use. 


\section{Methods and Data Analysis}

\section{Sample and Procedure}

The study followed the cross-sectional survey design. The study area is the Federal Medical Centre, Owo (FMC), Ondo State, South West, Nigeria on latitude $7.2076^{\circ} \mathrm{N}$ and longitude $5.5814^{\circ} \mathrm{E}$, and located along Ikare-Owo expressway. The total number of FMCs is 22 across Nigeria as a country. The majority of the centers are located in the state capital, especially in situations where the state-run apex secondary health institution does not adequately meet the citizen's requirements for specialized health care. It is the responsibility of Local governments to provide primary healthcare in Nigeria, while the State Government her responsible for secondary healthcare, and the federal government is in charge of tertiary healthcare (Aregbeshola \& Khan, 2017). In enforcing this policy, the Federal Government agreed to create in each Nigerian Federation State at least one tertiary health institution. Federal Medical Centers (FMCs) have been developed nation-wide in states that do not have teaching hospitals at Federal University. The exception to this rule is Lagos State, which besides a Teaching Hospital, has one such center. The population of the study consists of both the administrative and clinical staff of the institution. The population for the study is selected based on the number of permanent staff in FMC, Owo, whose salaries are paid via bank.

The sample of this research was calculated using Yamane formula as cited by Israel (1992) with a 95\% confidence level. The sample size calculated was 304 respondents. Data were collected with the aid of a structured questionnaire. Both dependent and independent variables were composite or latent variables measure with a 5-point Likert scale. The first and second objectives are descriptive, so the analyzes involved mean rating and standard deviation. The last objective involves the use of variance-based structural equation modeling of constructs of TAM and that of factors of customer satisfaction. Therefore, this analyzes employs the SmartPLS version 3.2.8 to execute the measurement model and the structural model according to the procedure by Hair et al. (2019).

\section{Results and Discussion}

\section{Socio-Demographic}

Three hundred and four (304) copies of the questionnaire were administered, out of which two hundred and eighty-four (284) questionnaire, which represents $93.4 \%$ were retrieved. The gender characteristics show that male respondents dominated, representing $53.9 \%$, while the female respondents were $46.1 \%$. It also shows that $16.2 \%$ were below 25 years of age, $32 \%$ were between twenty-five and thirty-four years, $34.9 \%$ were between thirty-five and forty-four years, $14.8 \%$ were between forty-five and fifty-four years of age while $2.1 \%$ were fiftyfive years and above. This reveals that $66.9 \%$ of the respondents were within the active working-age group of twenty-five years and forty-four years.

Nineteen percent (19\%) of the respondents had less than one year of relevant work experience. And the $15.1 \%$ had between one and five years of relevant work experience, Whereas $26.1 \%$ had between six and ten years of relevant work experience, while $39.8 \%$ of the total respondents had more than ten years of relevant career experience. The majority of the respondents were within the age brackets that can experiment and take the risk, unlike the older people who are dogmatic or would instead rely on paperwork.

Also, data reveals that $53.5 \%$ of the respondents were clinical staff, while $46.5 \%$ were the administrative staff. The percentages of the respondents holding Postgraduate/Higher Degree, Diploma, and secondary education, were $18.7 \%, 15.8 \%$, and $3.2 \%$, respectively. The majority of the respondents $(62.3 \%)$ had BSc / HND. Degree. The cumulative percentage of those who had a First Degree and above was $81 \%$. 81\% of respondents with first 
degrees and above have shown faith in the results obtained in this study. This affirmed that the composition of the study respondents were those knowledgeable enough to provide quality information for this study.

\section{Hypothesis Testing}

\section{Perceived Usefulness and Perceived Ease of Use of Electronic Banking System}

The mean response rating values for the items on TAM constructs (Perceived Usefulness and Perceived Ease of Use) ranges from a maximum of 4.5035 (PU6, "Use of e-banking improves banking operations") to a minimum of 3.6021 (PEOU6, "All e-banking functions are easy to use with less experience"). Only one indicator mean value scores were above 4.50, and none was less than 1.81, which indicates that all of these items were considered highly valuable.

The results presented shows that the mean values of all the indicators are higher than 3.50 . These results suggest that the levels of perceived usefulness and perceived ease of use of e-banking stakeholders pay more considerable attention to the usefulness of e-banking, implying that the usefulness of a technology to be adopted is considered crucial among the respondents. Besides, the mean values for all the indicators measuring the levels of perceived usefulness were above 4.00, suggesting that benefits derived from technology are also significant to the adoption of the technology.

Also, all the PU indicators were rated 'very high.' The mean values ranged between 4.50 and 4.38. Averagely, the level of perceived usefulness of e-banking in the study area was rated very high with a mean value of 4.41.

Furthermore, all the indicators measuring PEOU of e-banking were rated 'high' except PEOU2, which was rated 'very high'. The mean values ranged between 4.30 and 3.60. Averagely, the level of perceived ease of use of e-banking in the study area was rated 'high' with a mean value of 4.03. Comparatively, the level of PU was found to be higher than the level of PEOU of e-banking in the study area. This implies that the use of technology adopted was considered to be more critical than its ease of use. E-banking users are more attracted to e-banking channels due to benefits to be derived than the flexibility of the user's interface. On the part of FMC staff, necessity is more important, and that was reflected in the result obtained.

Focusing on the ten most highly ranked indicators, the adoption of e-banking by customers of deposit money banks in the study area, strongly depends on the usefulness of the e-banking channels than the ease of use of those channels. This is because the necessity and importance of e-banking to members of staff of FMC Owo outweigh the challenges therein. Hence, deposit money banks should concentrate more on the usefulness and benefits of e-banking channels without neglecting the flexibility of the user's interfaces of those channels.

\section{The extent of Satisfaction in the Electronic Banking System}

The data analysis showed the level of satisfaction in the use of the electronic banking system by the staff of the Federal Medical Centre, Owo. The mean values of the items for satisfaction vary from 4.31 to 3.31. Thus, all the respondents have a different perception of the levels of satisfaction in the electronic banking system. The results revealed that the level of satisfaction on time-saving characteristics (4.31) was rated very high. In contrast, the availability of the electronic banking system (4.14), speed of transactions (4.07), ease of banking (4.04), and accessibility of electronic banking system (4.00) was rated highly. Also, absent of unnecessary costs (3.89), adaptability (3.88), affordability (3.88), access to transaction records (3.77), levied fees (3.72), security (3.64), and proximity of electronic banking system (3.46) was rated highly. However, the level of satisfaction with the electronic banking network service (3.31) was rated moderately high. Ololade and Ogbeide (2017) in their study on e-banking in Nigeria: issues and challenges, concluded that network loss from internet connection is the major challenge facing customers using e-banking products in Nigeria and, therefore, the experience noticeable 
in Owo is not an exception, hence the result obtained. Averagely, the level of e-banking satisfaction, as rated by the respondents, revealed a mean of 3.85. This rated high as well.

\section{Effects Of Perceived Usefulness, Perceived Ease Of Use And Actual System Use Of Electronic Banking System On The Extent Of Satisfaction}

This study has applied the principle of partial least square to provide information on the constructs relationship. The approach involves the measurement model evaluation of the outer model and the inner model for the structural paths. The two sequences were conducted to help guarantee that manifests from each of the constructs are valid and reliable before the study can draw any meaningful conclusions on the relationships.

\section{Measurement Model}

In this study, PU, PEOU, ATU, BIU, and ASU constructs were reflectively operationalized. Whereas, customer satisfaction involves carrying-out a formative measurement model procedure. The measurement model, therefore, commenced with the procedures for the reflective model and, after that, followed by the procedure for the formative measured construct. First, the procedure for reflective measurement involves internal consistency reliability, convergent validity, and discriminant validity. The internal consistency of the constructs was evaluated using Cronbach's alpha and composite reliability approach, as proposed by (Hair et al., 2017). Both Cronbach's alpha and composite reliability have a threshold of 0.7 with higher values indicating a higher level of reliability (Herath \& Rao, 2009). Nevertheless, it is feasible to get suitable reliability for values between 0.60 as well as 0.70 , though one other validity coefficients need to be adequate (Hair et al., 2017).

Table 1 - Reliability and Validity of Constructs

\begin{tabular}{lcccc}
\hline & Cronbach's Alpha & rho_A & Composite Reliability & Average Variance Extracted (AVE) \\
\hline asu & 0.807 & 0.826 & 0.874 & 0.635 \\
atu & 0.850 & 0.879 & 0.894 & 0.633 \\
biu & 0.849 & 0.855 & 0.886 & 0.529 \\
peou & 0.886 & 0.889 & 0.912 & 0.597 \\
pu & 0.887 & 0.893 & 0.910 & 0.561 \\
\hline
\end{tabular}

Table 1 shows that the Cronbach's alpha values range from 0.809 to 0.887 , and composite reliability also ranges from 0.874 to 0.912 . The results show that reflective constructs have no issues of reliabilities as they surpass the recommended threshold of 0.7 for both tests (Hair et al., 2019). Table 1 also reveals the outcomes of the average variance extracted an indication of the convergent validity; the values range from 0.529 to 0.635 , which are above the recommended value of 0.5 (Hair et al., 2017; Bagozzi \& Yi, 1988).

Furthermore, the discriminant validity of the constructs examined based on their cross-loadings, FornellLarcker criterion, and the assessment of the correlations HTMT. The outcome of the cross-loadings expected that in the assessment, the outer loading of an indicator (Figure 3) needs to be more significant on its latent variable in comparison with its cross-loadings on the other constructs. 


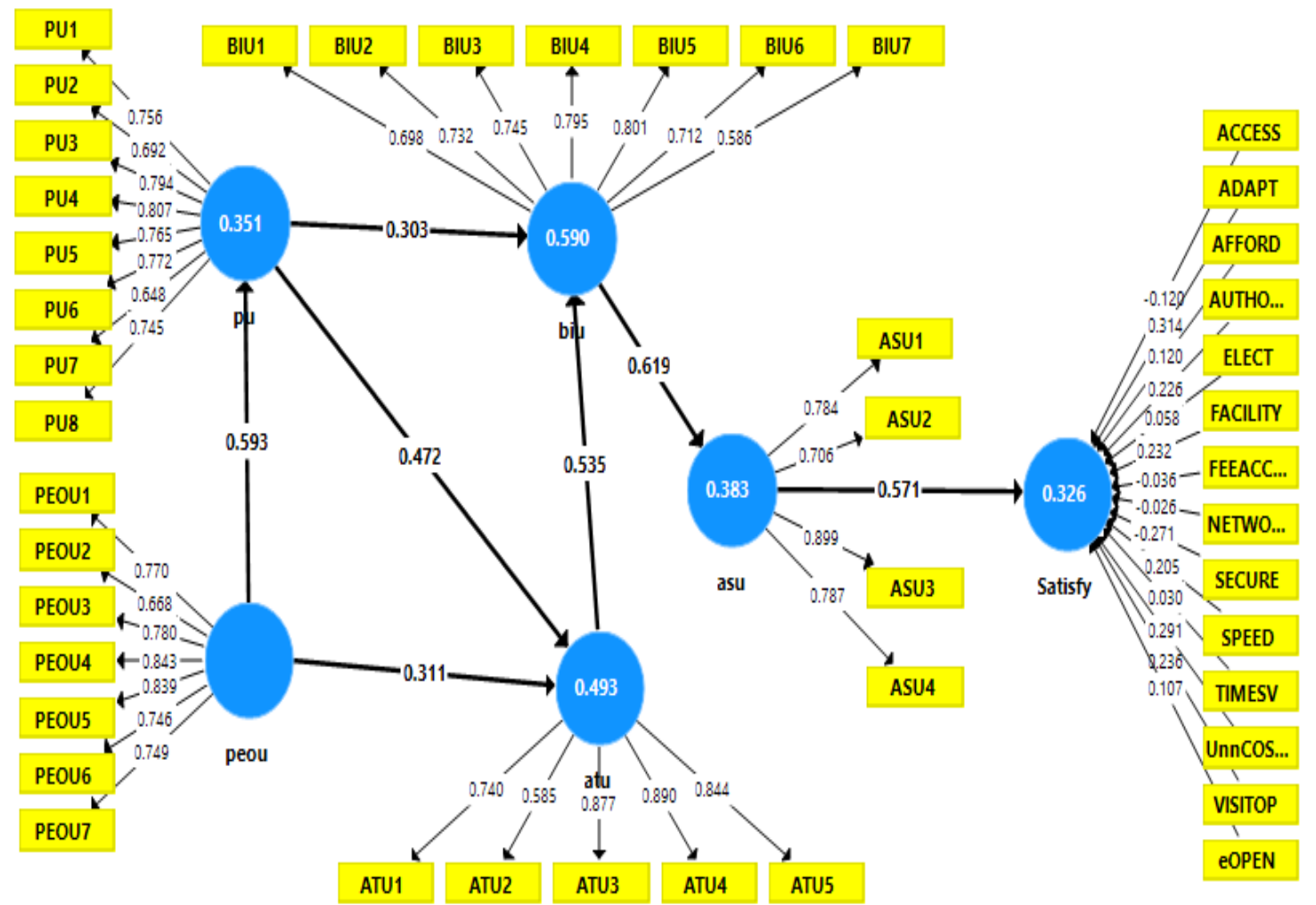

Figure 3 - Measurement model showing outer loadings and weights (PLS-Algorithm)

Table 2 - Cross Loadings

\begin{tabular}{llllll}
\hline & asu & atu & biu & peou & pu \\
\hline ASU1 & 0.784 & 0.558 & 0.595 & 0.537 & 0.452 \\
ASU2 & 0.706 & 0.263 & 0.347 & 0.389 & 0.265 \\
ASU3 & 0.899 & 0.433 & 0.552 & 0.459 & 0.361 \\
ASU4 & 0.787 & 0.355 & 0.439 & 0.402 & 0.328 \\
ATU1 & 0.322 & 0.740 & 0.523 & 0.446 & 0.474 \\
ATU2 & 0.319 & 0.585 & 0.366 & 0.263 & 0.361 \\
ATU3 & 0.405 & 0.877 & 0.620 & 0.496 & 0.583 \\
ATU4 & 0.448 & 0.890 & 0.680 & 0.490 & 0.591 \\
ATU5 & 0.538 & 0.844 & 0.664 & 0.591 & 0.562 \\
BIU1 & 0.353 & 0.512 & 0.698 & 0.429 & 0.424 \\
BIU2 & 0.428 & 0.531 & 0.732 & 0.461 & 0.530 \\
BIU3 & 0.436 & 0.546 & 0.745 & 0.395 & 0.442 \\
BIU4 & 0.431 & 0.631 & 0.795 & 0.413 & 0.558 \\
BIU5 & 0.504 & 0.585 & 0.801 & 0.427 & 0.518 \\
BIU6 & 0.526 & 0.488 & 0.712 & 0.440 & 0.446 \\
BIU7 & 0.471 & 0.418 & 0.586 & 0.350 & 0.385 \\
PEOU1 & 0.413 & 0.405 & 0.404 & 0.770 & 0.450 \\
PEOU2 & 0.396 & 0.462 & 0.444 & 0.668 & 0.467 \\
PEOU3 & 0.469 & 0.503 & 0.470 & 0.780 & 0.450 \\
PEOU4 & 0.422 & 0.506 & 0.447 & 0.843 & 0.478 \\
PEOU5 & 0.414 & 0.486 & 0.445 & 0.839 & 0.492
\end{tabular}




\begin{tabular}{|c|c|c|c|c|c|}
\hline PEOU6 & 0.504 & 0.395 & 0.434 & 0.746 & 0.405 \\
\hline PEOU7 & 0.446 & 0.414 & 0.448 & 0.749 & 0.452 \\
\hline PU1 & 0.377 & 0.456 & 0.511 & 0.433 & 0.756 \\
\hline PU2 & 0.359 & 0.405 & 0.437 & 0.352 & 0.692 \\
\hline PU3 & 0.347 & 0.504 & 0.464 & 0.501 & 0.794 \\
\hline PU4 & 0.361 & 0.601 & 0.578 & 0.496 & 0.807 \\
\hline PU5 & 0.333 & 0.555 & 0.526 & 0.498 & 0.765 \\
\hline PU6 & 0.295 & 0.481 & 0.455 & 0.396 & 0.772 \\
\hline PU7 & 0.258 & 0.404 & 0.427 & 0.371 & 0.648 \\
\hline PU8 & 0.350 & 0.482 & 0.495 & 0.470 & 0.745 \\
\hline
\end{tabular}

Table 2 demonstrates that the outer loading of each indicator is higher on its respective construct when compared with its cross-loadings on another construct with no less than a difference of 0.10 suggested by Gefen and Straub (2005). Another technique concerned the Fornell-Larcker criterion, which proposed that every construct's AVE, need to be compared to the squared inter-construct correlation of that same particular construct and any other reflectively measured constructs within the structural model (Hair et al., 2017). Furthermore, the shared variance for all of the model constructs should not be bigger when compared to their AVEs.

Table 3 - Fornell-Larcker Criterion

\begin{tabular}{llllll}
\hline & Asu & atu & biu & peou & pu \\
\hline asu & $\mathbf{0 . 7 9 7}$ & & & & \\
atu & 0.518 & $\mathbf{0 . 7 9 6}$ & & & \\
biu & 0.619 & 0.733 & $\mathbf{0 . 7 2 7}$ & & \\
peou & 0.565 & 0.591 & 0.573 & $\mathbf{0 . 7 7 3}$ & \\
pu & 0.448 & 0.656 & 0.654 & 0.593 & $\mathbf{0 . 7 4 9}$ \\
\hline
\end{tabular}

Table 3 shows that this recommendation on AVE has been achieved. The study went further to assess the HTMT in light of the limitation of the AVE technique (Hair et al., 2017). It is recommended that a value above 0.90 displays a lack of discriminant validity (Henseler et al., 2015). Moreover, the confidence interval of the HTMT should not include the value 1.

Table 4 shows that the HTMT criterion has been satisfied with the study PLS model.

Table 4 - HTMT

\begin{tabular}{llllll}
\hline & asu & atu & biu & peou & pu \\
\hline asu & & & & & \\
atu & 0.607 & & & \\
biu & 0.737 & 0.847 & & \\
peou & 0.667 & 0.663 & 0.663 & 0.662 \\
pu & 0.522 & 0.742 & 0.747 & \\
\hline
\end{tabular}

Unfortunately, the traditional reliability and validity procedure conducted for a reflective construct cannot be used for a formative indicator. This study followed the procedures according to Hair et al. (2017) and Xu, Peng, and Prybutok (2019). The first criteria are to identify any multicollinearity issue. For the formative construct's reliability, high multicollinearity suggests the presence of redundant indicators. Any value of variance inflation factor (VIF) above 5 indicates the presence of multicollinearity (Hair. et al., 2017). However, Diamantopoulos and Signaw (2006) suggested a more conservative value of VIF at 3.3. A close look at Table 5 shows that the outer VIF values range from 1.423 to 2.916. The study, therefore, concludes that collinearity does not violate 
its critical levels in the formative construct, customer satisfaction, and it is not an issue for the estimation of the PLS path model in this study. The next procedure under formative assessment is the need to analyze the outer weights for their significance and relevance. The criteria involve first knowing whether the indicator's outer weight is significant or not. For a nonsignificant weight, the procedure entails examining its outer loading if it is above 0.50 . The indicator should be interpreted as essential but not as relatively necessary (Hair et al., 2017). This guarantees that the indicator should be retained. Otherwise, if an indicator has a nonsignificant weight and the outer loading is below 0.50 , it is left for the study to decide whether to retain or eliminate such an indicator by examining its theoretical relevance and potential overlap with other indicators of the same construct. But, if the outer loading is below 0.10 and a nonsignificant weight, there is no empirical justification for such an indicator to be retained as it is neither relevance. This study examines the significance of the outer weights using bootstrapping (Figure 4).

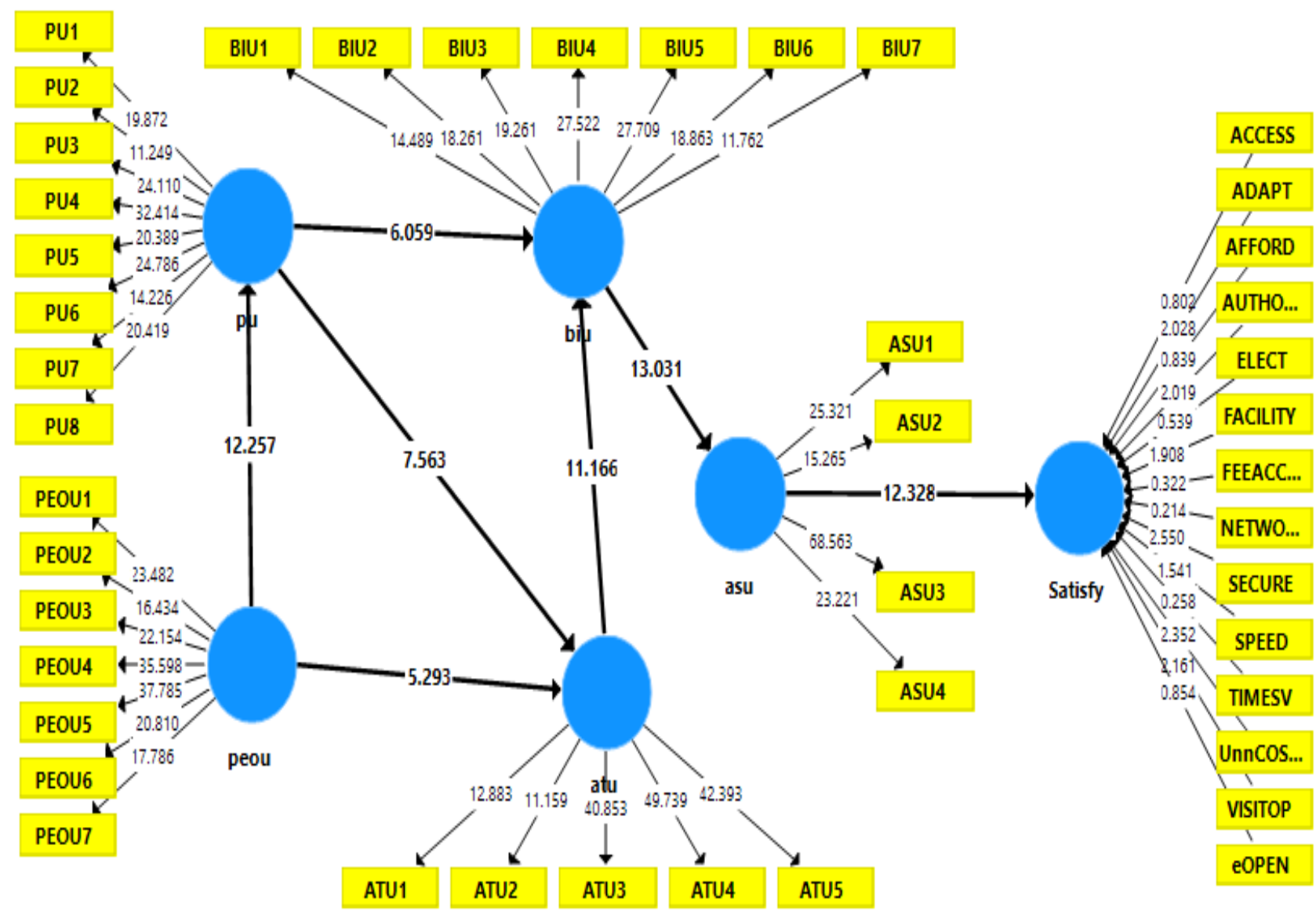

Figure 4 - Measurement model bootstrapping

Table 5 shows the report that only two indicators, electricity, and network, have their outer weights nonsignificant and outer loadings of 0.488 and 0.481 , respectively. But because their loadings are far above 0.10 as well as VIFs are adequate, the study decided to retain these indicators and assumed relevant. Finally, the study has examined the measurement models for reflective and formative indicators, all the criteria have been successfully adequate, and there is no reason to delete any indicator at this stage. 
Table 5 - Assessment of formative measurement model

\begin{tabular}{lllllllll}
\hline & Loading & Weight & T Statistics & P Values & Bias & $\mathbf{2 . 5 0 \%}$ & $\mathbf{9 7 . 5 0 \%}$ & VIF \\
\hline ACCESS -> Satisfy & 0.632 & -0.120 & 0.802 & 0.423 & 0.012 & -0.463 & 0.152 & 2.833 \\
ADAPT -> Satisfy & 0.690 & 0.314 & 2.028 & 0.043 & -0.012 & 0.043 & 0.641 & 2.916 \\
AFFORD -> Satisfy & 0.613 & 0.120 & 0.839 & 0.402 & -0.022 & -0.157 & 0.391 & 2.340 \\
AUTHORIZE - > Satisfy & 0.625 & 0.226 & 2.019 & 0.044 & -0.011 & 0.028 & 0.449 & 1.703 \\
ELECT -> Satisfy & 0.488 & 0.058 & 0.539 & 0.590 & -0.002 & -0.137 & 0.299 & 1.423 \\
FACILITY -> Satisfy & 0.634 & 0.232 & 1.908 & 0.057 & -0.014 & 0.001 & 0.468 & 1.781 \\
FEEACCEPT -> Satisfy & 0.625 & -0.036 & 0.322 & 0.747 & -0.003 & -0.230 & 0.200 & 1.831 \\
NETWORK -> Satisfy & 0.481 & -0.026 & 0.214 & 0.830 & 0.006 & -0.321 & 0.175 & 1.689 \\
SECURE -> Satisfy & 0.314 & -0.271 & 2.550 & 0.011 & 0.017 & -0.500 & -0.093 & 1.575 \\
SPEED -> Satisfy & 0.630 & 0.205 & 1.541 & 0.124 & -0.011 & -0.036 & 0.481 & 1.634 \\
TIMESV -> Satisfy & 0.568 & 0.030 & 0.258 & 0.796 & 0.004 & -0.219 & 0.250 & 1.673 \\
UnnCOSTS -> Satisfy & 0.768 & 0.291 & 2.352 & 0.019 & -0.008 & 0.066 & 0.548 & 2.133 \\
VISITOP -> Satisfy & 0.626 & 0.236 & 2.161 & 0.031 & -0.007 & 0.036 & 0.454 & 1.510 \\
eOPEN -> Satisfy & 0.672 & 0.107 & 0.854 & 0.394 & -0.010 & -0.134 & 0.339 & 2.084 \\
\hline
\end{tabular}

\section{Assessment of structural model}

This section treats the last objective of the study. Although the approach takes care of the structural paths of TAM and customer satisfaction constructs yet, the study is focused on the exogenous variables PU, PEOU, and ASU on the endogenous variable Satisfy $\left(\mathrm{H}_{1}, \mathrm{H}_{2}\right.$, and $\mathrm{H}_{3}$, as shown in Figure 2). The study employed a structural equation model to examine the collinearity, the coefficient of determination (R-square), path coefficients ( $\beta$ ), and effect sizes (f-square). Foremost, the values of inner VIF (Table 6 ) reveal 1.584, 1,863, and 1.519 for PU, PEOU, and ASU, respectively, on the endogenous composite variable (satisfy). The obtained

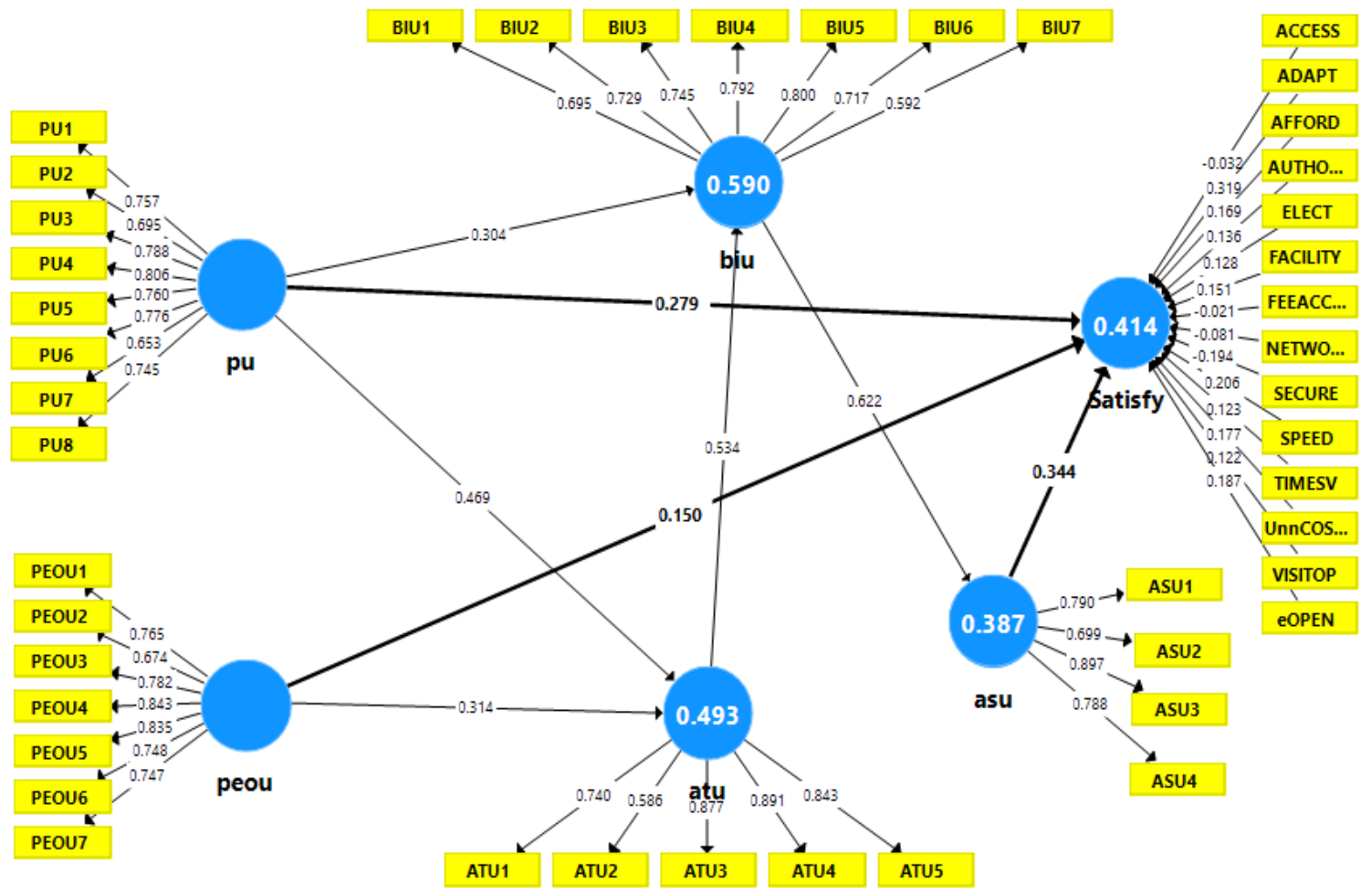

Figure 5 - Structural Path Analysis (PLS-Algorithm) 
results have shown that there is no issue of multicollinearity among the latent variables as they are all below the threshold value of 5 .

After the exogenous variables found adequate for the VIF test, the PLS-algorithm (Figure 5) and bootstrapping (Figure 6) were conducted with 5000 resamples using PLS 3.2.8 to get the standard path coefficients, t-statistic values, standard deviations, and p-values (Hair et al., 2017). Table 6, Figures 5\&6 disclose the direct path coefficients for perceived usefulness (PU), perceived ease of use (PEOU) and actual system use (ASU) constructs and illustrate positives and significant relationship with $\operatorname{PU}(\beta=0.279, \mathrm{t}=3.213), \operatorname{PEOU}(\beta=0.150$, $\mathrm{t}=1.851)$ and $\operatorname{ASU}(\beta=0.344, \mathrm{t}=4.188)$, respectively. Thus, PU and ASU hypotheses are supported at a 99 percent level of significance. However, the path hypothesis of PEOU is supported at a 90 percent level of significance.

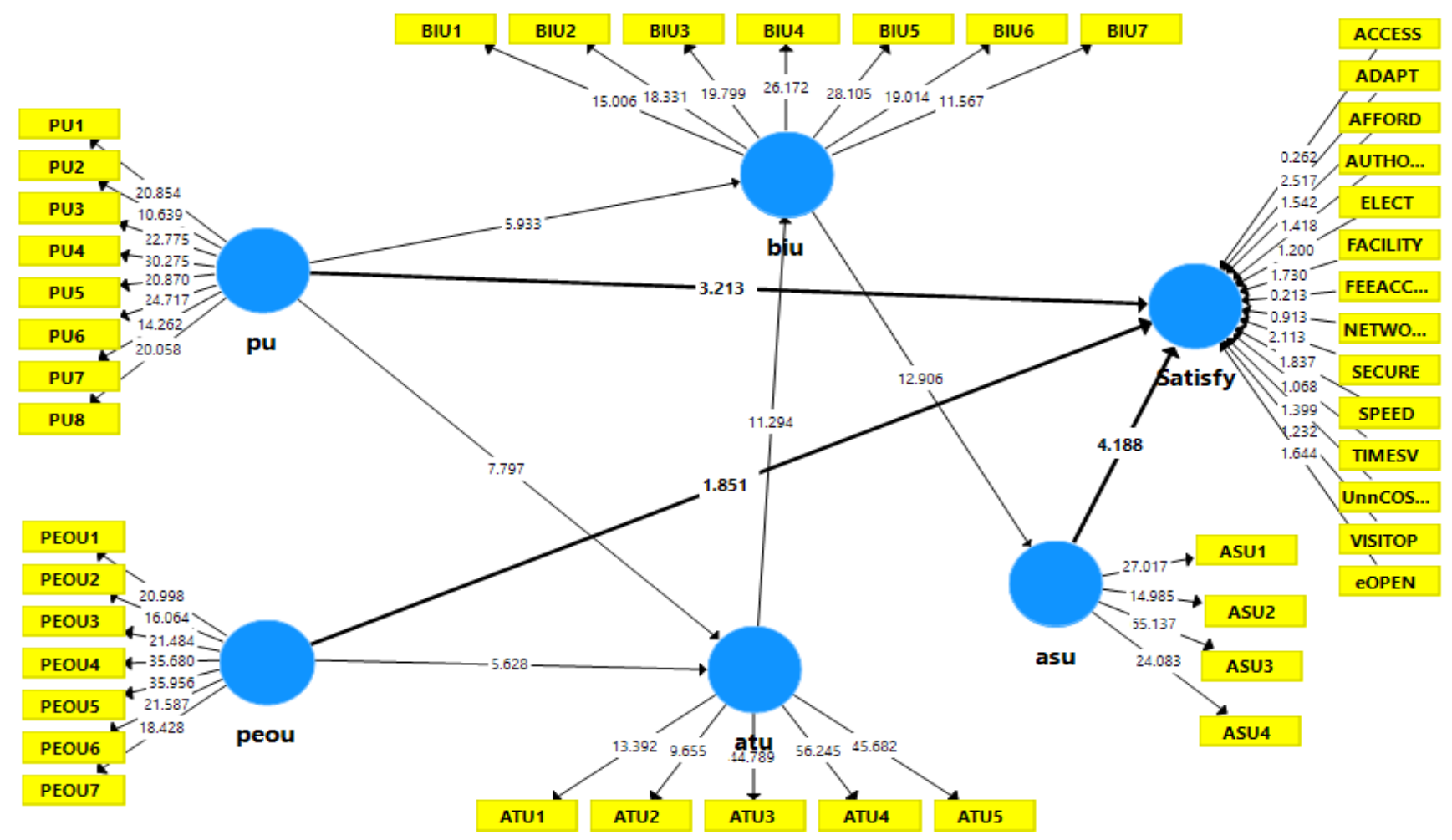

Figure 6 - Bootstrapping of the Structural Path

Table 6 also reports the value of the coefficient of determination (R-square) as 0.414 . According to Cohen, as reported in Tehseen et al. (2019), suggested that R-square values of $0.26,0.13$, and 0.02 should be considered as substantial, moderate, and weak, respectively. Therefore, the R-square value of the endogenous construct can be said to be substantial because it is more than 0.26 , as suggested. Hence the exogenous study variables (PU, PEOU, and ASU) were able to explain 41 percent of the variance in the endogenous construct (Satisfy). Then, the study further examined the effect size (f-square). According to the recommended threshold by Cohen, as reported in Tehseen et al. (2019), the values of the f-square effect size $0.02,0.15$, and 0.35 are considered as small, medium, and significant effects of the exogenous constructs, respectively. Following this guideline, Table 6 shows that PU, PEOU, and ASU do have small effect sizes of 0.084, 0.021, and 0.133, respectively, on customer satisfaction. 
Table 6 - Structural Path Analysis

\begin{tabular}{lcccccccc}
\hline Hypothesis: Path & $\boldsymbol{\beta}$-value & SD & t-statistic & p-value & $\begin{array}{c}\mathbf{9 5 \%} \text { Bca } \\
\text { Confidence Interval }\end{array}$ & VIF & f-square & Decision \\
\hline H1: pu-->satisfy & 0.279 & 0.087 & $3.213^{* * *}$ & 0.001 & {$[0.118,0.406]$} & 1.584 & 0.084 & supported \\
H2: peou-->satisfy & 0.150 & 0.081 & $1.851^{*}$ & 0.065 & {$[0.003,0.273]$} & 1.863 & 0.021 & supported \\
H3: asu-->satisfy & 0.344 & 0.082 & $4.188^{* * *}$ & 0.000 & {$[0.206,0.469]$} & 1.519 & 0.133 & supported \\
R-square & 0.414 & & & & & & &
\end{tabular}

Notes: Critical t-values: $* 1.65($ significance level $=10 \%) ; * * 1.96($ significance level $=5 \%)$; and $* * * 2.57($ significance level $=1 \%)$

\section{Discussions and Implications}

The research has raised awareness of the factors, which are likely to determine user's satisfaction of e-banking in unnatural environments, with the support of the Technology Acceptance Model. This drawn from various theories of behavioral intention has helped to bring specific, powerful influences to the limelight. That discourages or increase customers' incidences of the level of satisfaction with the e-banking channels. By adopting TAM in this research, this study assessed the levels of perceived usefulness and perceived ease of use of e-banking. The result formed the detail that users find perceived usefulness and perceived ease of use to be clear determining factors in adopting e-banking system, with more emphasis on its perceived usefulness. This shows that although consumers perceived electronic banking platforms to be beneficial; however, consumers are yet to embrace this innovation due to many factors such as the flexibility of the user's interface. This also shows that being informed alone is not enough to persuade customers to use the self-service, but this has to do with their perceived ease of use of the service.

Secondly, the study correspondingly examined the factors, which influenced the consumers' level of satisfaction with electronic banking platforms. The research framework developed was based on the indicators of Time Saving, Availability, Speed of transactions, Easy banking operations, Accessibility, Limited unnecessary costs, Adaptability, Affordability, Access transaction records, Acceptable levied fees, Security, Proximity of electronic banking channels, and Network Service. All these factors have some level of contribution to the consumer's level of satisfaction with electronic banking systems. From this research finding, the level of satisfaction was rated high (Mean $=3.85$ ). However, the level of consumers' satisfaction with the network service was a bit low (Mean $=3.31)$. Furthermore, this study confirmed that the actual system use of the electronic banking system has a significant effect on the extent of satisfaction of the consumers with the causal variable influencing the dependent variable to about 28.4 percent.

It should be recalled that the study performed the partial least square structural equation modeling, and as a result, all the hypotheses in this study were accepted. The study noted the smallest effect from PEOU because this does not matter to an environment occasioned with uncertainty as well as the respondents are a knowledgeable set of people who can reason and handle technology effectively. The effect of PU is found to be four times that of PEOU because the relative advantage of the technology is far more than what can be obtained presently in an unnatural environment as long queue continues to surface at the banks. These results corroborate the earlier studies of Isaac et al. (2017; 2018), Gbongli et al. (2019), Ding et al. (2019) and Islam, (2011). Similarly, actual system use of the electronic banking system has a significant effect on the extent of satisfaction of the staff of the Federal Medical Centre, Owo. This finding also gave credence to the study of Ayo et al., (2016) on e-banking users' behavior: e-service quality, attitude, and customer satisfaction but contrary to Pearson et al. (2012), Ayo et al., (2016) and Isaac et al. (2018)which found that customer satisfaction reveals no significant effect on actual use.

The findings imply that banks in Owo need to continue to meet the needs of their customers in the e-banking encounter requiring employee response, smooth transaction processing, the technical functioning of the system 
in terms of both a quality network and a proper functioning of system characteristics. Likewise, network availability indicates that banks will prosper more from ensuring secure networks that will allow e-banking technologies to be made available always. Suitable networks will also help avoid network failure and involuntary disruption when maintaining or updating the network infrastructure. Finally, it exceedingly evident that perceived relative advantage of technology is so huge to the staff of the medical center, Owo due to their level of education and particularly their nature of the job, which does not permit them to leave their duty post and wait endlessly for a service that may not materialize. As the queue may be endless due to the shortage of time, the banks operate has been reduced. In contrast, the use of banking technologies shows a great deal for the obtained results as perceived relative advantage takes its preeminent control of situations in an unnatural environment.

Funding: This research received no external funding.

Conflicts of Interest: The authors declare no conflict of interest.

\section{References}

Agrebi, S., \& Jallais, J. (2015). Explain the intention to use smartphones for mobile shopping. Journal of Retailing and Consumer Services, 22, 16-23. https://doi.org/10.1016/j.jretconser.2014.09.003

Akinwale, Y. O., \& Adepoju, A. O. (2019). Factors influencing willingness to adopt renewable energy technologies among micro and small enterprises in Lagos state Nigeria. International Journal of Sustainable Energy Planning and Management, 19. https://doi.org/10.5278/ijsepm.2019.19.7

Akinyemi, I. O., Asani, E. O. \& Adigun, A. A. (2013). An Investigation of Users ' Acceptance and Satisfaction of E-Banking System as a Panacea towards a Cashless Economy in Nigeria. Journal of Emerging Trends in Computing and Information Sciences, 4(12), 954-963.

Amin, M. (2016). Internet banking service quality and its implication on e-customer satisfaction and e-customer loyalty. International Journal of Bank Marketing. https://doi.org/10.1108/IJBM-10-2014-0139

Amin, M., Rezaei, S., \& Abolghasemi, M. (2014). User satisfaction with mobile websites: the impact of perceived usefulness (PU), perceived ease of use (PEOU) and trust. Nankai Business Review International, 5(3), 258-274. https://doi.org/10.1108/NBRI-01-2014-0005

Aregbeshola, B. S., \& Khan, S. M. (2017). Primary health care in Nigeria: 24 years after Olikoye Ransome-Kuti's leadership. In Frontiers in Public Health. https://doi.org/10.3389/FPUBH.2017.00048

Ayo, C. k., Oni, A. A., Adewoye, O. J., \& Eweoya, I. O. (2016). E-banking users' behaviour: e-service quality, attitude, and customer satisfaction. International Journal of Bank Marketing. https://doi.org/10.1108/IJBM-12-2014-0175

Bagozzi, R., \& Yi, Y. (1988). On the Evaluation of Structural Equation Models. Journal of the Academy of Marketing Science, 16(1), 74-94. https://doi.org/https://doi.org/10.1007/BF02723327

Chen, S. C., Chen, H. H., \& Chen, M. F. (2009). Determinants of satisfaction and continuance intention towards self-service technologies. Industrial Management and Data Systems, 109(9), 1248-1263. https://doi.org/10.1108/02635570911002306

Davis, F. D. (1989). Perceived usefulness, perceived ease of use, and user acceptance of information technology. MIS Quarterly: Management Information Systems. https://doi.org/10.2307/249008

Ding, Z., Saide, S., Siti Astuti, E., Muwardi, D., Najamuddin, N., Jannati, M., \& Herzavina, H. (2019). An adoption of acceptance model for the multipurpose system in university library. Economic ResearchEkonomska Istrazivanja, 32(1), 2393-2403. https://doi.org/10.1080/1331677X.2019.1635898

Gefen, D., \& Straub, D. (2005). A Practical Guide To Factorial Validity Using PLSGraph: Tutorial And Annotated Example. Communications of the Association for Information Systems, 16(5), 91-109. https://doi.org/DOI: 10.17705/1CAIS.01605

Gbongli, K., Xu, Y., \& Amedjonekou, K. M. (2019). Extended technology acceptance model to predict mobile- 
based money acceptance and sustainability: A multi-analytical structural equation modeling and neural network approach. Sustainability (Switzerland), 11(13), 1-33. https://doi.org/10.3390/su11133639

George, A., \& Kumar, G. S. G. (2013). Antecedents of Customer Satisfaction In Internet Banking: Technology Acceptance Model (TAM) Redefined. Global Business Review, 14(4), 627-638. https://doi.org/10.1177/0972150913501602

Ghani, M. A., Rahi, S., \& Yasin, N. M. (2017). Adoption of Internet Banking : Extending the Role of Technology Acceptance Model ( TAM ) with E-Customer Service and Customer Satisfaction Graduate School of Business, Universiti Kebangsaan Malaysia. World Applied Sciences Journal, 35(9), 1918-1929. https://doi.org/10.5829/idosi.wasj.2017.1918.1929

Hair, J.F., Hult, G.T.M., Ringle, C.M., Sarstedt, M. (2017). A Primer on Partial Least Squares Structural Equation Modeling (PLS-SEM) (J. Hair (ed.); Second Edi). Sage.

Hair, Joe F, Risher, J. J., Sarstedt, M., \& Ringle, C. M. (2019). The Results of PLS-SEM Article information. European Business Review, 31(1), 2-24. https://doi.org/10.1108/EBR-11-2018-0203

Hair, Joseph F., Risher, J. J., Sarstedt, M., \& Ringle, C. M. (2019). When to use and how to report the results of PLS-SEM. European Business Review, 31(1), 2-24. https://doi.org/10.1108/EBR-11-2018-0203

Henseler, J., Ringle, C. M., \& Sarstedt, M. (2015). A new criterion for assessing discriminant validity in variancebased structural equation modeling. Journal of the Academy of Marketing Science, 43, 115-135. https://doi.org/DOI 10.1007/s11747-014-0403-8

Herath, T., \& Rao, H. R. (2009). Protection motivation and deterrence: A framework for security policy compliance in organisations. European Journal of Information Systems. https://doi.org/10.1057/ejis.2009.6

Isaac, O., Abdullah, Z., Ramayah, T., \& Mutahar, A. M. (2017). Internet Usage within Government Institutions in Yemen: An Extended Technology Acceptance Model (TAM) with Internet Self-Efficacy and Performance Impact. Science International, 29(4), 737-747.

Isaac, O., Abdullah, Z., Ramayah, T., Mutahar, A. M., \& Alrajawy, I. (2018). Integrating User Satisfaction and Performance Impact with Technology Acceptance Model (TAM) to Examine the Internet Usage Within Organizations in Yemen. Asian Journal of Information Technology, 17(1), 60-78. https://doi.org/10.3923/ajit.2018.60.78

Islam, A. Y. M. A. (2011). Viability of the extended technology acceptance model: An empirical study. Journal of Information and Communication Technology.

Israel Glenn.D. (1992). Determining sample size degree of variability strategies for determining sample size. 1IFAS, University of Florida. https://doi.org/10.1016/j.envpol.2016.06.041

Kannabiran, G., \& Narayan, P. C. (2005). Deploying Internet banking and e-commerce-case study of a private-sector bank in India. Information Technology for Development. https://doi.org/10.1002/itdj.20025

Karjaluoto, H., Jarvenpaa, L., \& Kauppi, V. (2009). Antecedents of online banking satisfaction and loyalty: empirical evidence from Finland. International Journal of Electronic Finance, 3(3), 253. https://doi.org/10.1504/ijef.2009.027849

Ololade, B., \& Ogbeide, S. (2017). E-Bankingg in Nigeria: Issues and Challenges. Research Journal of Finance and Accounting, 8(6), 16-24. https://www.researchgate.net/publication/318491505_EBanking_in_Nigeria_Issues_and_Challenges

Pearson, A., Tadisina, S., \& Griffin, C. (2012). The Role of E-Service Quality and Information Quality in Creating Perceived Value: Antecedents to Web Site Loyalty. Information Systems Management, 29(3), 201-215. https://doi.org/DOI: 10.1080/10580530.2012.687311

Sedgwick, S. (2017). Retail Banking Remuneration Review Report. Retail Banking Remuneration Review.

Tandon, U., Kiran, R., \& Sah, A. N. (2016). Analysing the complexities of website functionality, perceived ease of use and perceived usefulness on customer satisfaction of online shoppers in India. International Journal 
of Electronic Marketing and Retailing, 7(2), 115-140. https://doi.org/10.1504/IJEMR.2016.077118

Tang, T.-W., \& Huang, R.-T. (2015). The Relationships among Trust, E-satisfaction, E-loyalty, and Customer Online Behaviors. International Journal of Business and Industrial Marketing, 1(2), 16-25. http://www.aascit.org/journal/ijbim

Tehseen, S., Ahmed, F. U., Qureshi, Z. H., Uddin, M. J., \& Ramayah, T. (2019). Entrepreneurial competencies and SMEs' growth: the mediating role of network competence. Asia-Pacific Journal of Business Administration. https://doi.org/https://doi.org/10.1108/ APJBA-05-2018-0084

Vuković, M., Pivac, S., \& Kundid, D. (2019). Technology Acceptance Model for the Internet Banking Acceptance in Split. Business Systems Research, 10(2), 124-140. https://doi.org/10.2478/bsrj-2019-022 